\title{
Estimations of serum arabinitol for diagnosing invasive candidosis
}

\author{
AG DEACON
}

From the Department of Bacteriology and Immunology, Western Infirmary, Glasgow, Scotland

SUMMARY Arabinitol concentrations were determined in 157 serum samples from 95 patients with suspected invasive candidosis and in 10 serum samples from healthy laboratory workers. Fifty eight of the 95 patients, subsequently diagnosed as not having invasive candidosis had concentrations of arabinitol below $1.2 \mu \mathrm{g} / \mathrm{ml}$ (mean 0.59 (SD) 0.26 ). Sera from the healthy laboratory workers gave similar results (mean $0.55(0.05)$ ). Concentrations above the normal range were found in 18 of the 19 cases of confirmed or probable invasive candidosis and in seven of eight patients with infected intravenous lines or cannulas and clinical evidence of systemic infection. Raised concentrations were also seen in 10 other patients, including nine with renal failure who did not have invasive infections. Multiple serum samples obtained from 33 patients showed that sequential estimations were of value for diagnosing a developing infection. Despite some difficulties of interpretation the technique is rapid and specific and is suitable for use in the diagnostic laboratory of a larger general hospital.

The diagnosis of serious Candida infections is unsatisfactory in many hospitals and often depends on circumstantial evidence of variable quality, including the persistent isolation of yeasts from normally sterile sites, proof of a rising antibody titre, repeated positive blood cultures, and clinical signs of an infection that persists despite apparently appropriate antibacterial treatment. ${ }^{12}$ Reliance on such criteria leads to missed or delayed diagnosis. ${ }^{34}$ The isolation of yeasts from some sites can be misleading and may reflect contamination from nearby sites of colonisation. Serological methods have been described by many workers but doubts remain with respect to their specificity and the interpretation of results. ${ }^{1}$ Histological evidence of tissue invasion by biopsy is often unavailable either because the patient is too ill for the procedure to be attempted or because the site is poorly identified or unapproachable. ${ }^{5}$ More specific methods of immunodiagnosis are currently under investigation, including detection of circulating antigens by latex agglutination, and enzyme or radioimmunoassay, and these have recently been reviewed by de Repentigny and Reiss. ${ }^{6}$

Rapid and accurate diagnosis of systemic candidosis is essential if reductions in morbidity or mortality

Accepted for publication 26 March 1986 are to be achieved; recent reports have suggested that gas-liquid chromatography may contribute to this end. ${ }^{7-9}$ In $1979-80$ two groups ${ }^{89}$ independently reported that the major metabolite of the clinically important Candida species, both in vivo and in vitro, was the polyol, D-arabinitol, derived from the metabolism of carbohydrates. ${ }^{10}$ Both groups found that the normal concentrations of $D$ or $L$-arabinitol in the serum of healthy control groups or of patients with simple colonisation or superficial infections were consistently less than $1.0 \mu \mathrm{g} / \mathrm{ml}$. By contrast, patients (and animals) with confirmed systemic disease showed concentrations that were usually greater than $1.0 \mu \mathrm{g} / \mathrm{ml}$. Patients in renal failure but without detectable systemic candidosis were also found to have increased concentrations of the metabolite in their sera. ${ }^{89}$

Subsequently, two prospective studies evaluated the approach under clinical conditions of usage ${ }^{112}$; and the Sloan Kettering group extended their original studies by investigating the incidence of arabinitol and arabinitol:creatinine (a:c) ratios in renal failure both in an animal model and in 25 patients with cancer. ${ }^{13-15}$ Most recently, de Repentigny et al quantitatively compared arabinitol, mannose, and mannan antigen detection in serum samples from infected and uninfected high risk patients and in normal blood donors. ${ }^{16} 17$

This paper reports the results of a two year study in 
the clinical microbiology laboratory of a large general hospital on sera obtained from patients in six Scottish hospitals in the Glasgow and Edinburgh regions.

\section{Patients and methods}

One hundred and fifty seven sera from 95 patients in hospitals in the Glasgow and Edinburgh regions were studied. More than one serum sample was obtained from 33 patients. Six sets of sera were obtained retrospectively (principally sent by Dr LJR Milne, mycologist at the Western General Hospital, Edinburgh) after invasive candidosis had been diagnosed and these were processed without knowledge of the patients' condition or other findings. All other sera were examined prospectively and were obtained from patients suspected of developing invasive candidosis. Increasingly, as the study progressed, the evaluation of the technique was linked with its use as an aid to diagnosis.

In preparing this paper, patients' case histories were reviewed and placed into one of three groups: patients who did not have invasive candidosis; patients with confirmed or probable invasive candidosis; and candidaemic patients with clinical signs of systemic infection who had infected intravenous lines or cannulas.

The criteria accepted as independent proof of invasive candidosis were histological and obtained either by biopsy or at necropsy. In the absence of histology documented cases of invasive candidosis were established by a combination of clinical and laboratory evidence. All the patients in this group were clinically judged to have invasive candidosis, but due to the variability of case presentations no absolute set of criteria could be used; each case, however, was carefully assessed using well recognised and established criteria. ${ }^{1-35}$ All had received steroids or cytotoxic drugs for underlying diseases such as carcinoma or leukaemia, or had received prolonged treatment with antibiotics for the treatment or prevention of bacterial infections, or a combination of the above. All showed clinical signs of a systemic infection, including a persistent and often fluctuating fever, and were not responding to broad spectrum antibiotics. Other evidence evaluated included the isolation (preferably repeated) of high numbers of yeasts from blood cultures or other normally sterile deep sites such as abscess, peritoneal fluid, lung aspirate, or urine; recorded observations of a clinical response to systemic antifungal drugs, or a significant rise in anticandidal antibody titres. In two heroin addicts fundiscopic signs of a typical candida endophthalmitis were accepted as evidence of a locally invasive infection, ${ }^{5}$ and three patients with peritoneal candidosis associated with continuous ambulatory peritoneal dialysis (CAPD) had $>10^{7}$ colony forming units $/ \mathrm{ml}$ of yeasts in three consecutive fluids, persistent leucocytosis, and peritoneal signs of infection. ${ }^{18}$ The use of the general terms "systemic" and "deep seated" is conventional and consistent with that of Odds ${ }^{1}$ and other workers. ${ }^{3}$

\section{GAS-LIQUID CHROMATOGRAPHY}

All gas-liquid chromatographic analyses were performed using a Perkin Elmer Sigma 3 gas chromatograph fitted with dual flame ionisation detectors and two 2.0 metre $\times 4 \mathrm{~mm}$ outer diameter glass columns packed with $3 \%$ SE 30 on $80 / 100$ mesh Chromosorb W-HP (Chromatograpy Services Ltd, Hoylake, Merseyside, England). The nitrogen carrier rate was $20 \mathrm{ml} / \mathrm{minute}$ and the oven temperature was programmed to rise from $140^{\circ} \mathrm{C}$ to $200^{\circ} \mathrm{C}$ at $4^{\circ} /$ minute.

\section{SAMPLE PROCESSING AND STANDARDISATION} Serum arabinitol concentrations were measured using a modification of the method described by Kiehn et al. ${ }^{89}$ Thus $200 \mu \mathrm{l}$ of serum were mixed with $400 \mu \mathrm{l}$ of acetone containing $5.0 \mu \mathrm{g} / \mathrm{ml}$ of internal standard in a glass stoppered centrifuge tube. The precipitated proteins were removed by centrifuging the mixture at $1500 \mathrm{~g}$ for five minutes; the supernatant was collected into another glass centrifuge tube and dried at $50^{\circ} \mathrm{C}$ under a stream of oxygen free nitrogen (OFN). Trimethylsilyl derivatives (TMS) were then prepared by adding $0.1 \mathrm{ml}$ of a 9:3:1 mixture of pyridine, hexamethyldisilazine, and trimethylchlorosilane (Sylon HTP, Supelco, available from RB Radley and Co Ltd, England) and incubated at room temperature for 30 minutes. This mixture was then dried again under OFN at $50^{\circ} \mathrm{C}$ and resuspended in $0.12 \mathrm{ml}$ of pure diethyl ether ${ }^{19}$ (anhydrous puriss, AR Koch-Light Laboratories Ltd). 3.0 $\mu$ l of this extract were immediately injected into the gas chromatograph.

The internal standards were a-methyl-Dmannopyrannoside and $\beta$-methyl-D-xyloside (Sigma). ${ }^{13} 14$

An external standard consisting of pooled normal human serum containing arabinitol to a final concentration of $5.0 \mu \mathrm{g} / \mathrm{ml}$ was processed periodically as required to monitor any variations in sensitivity or flow rates. Arabinitol concentrations in test sera were calculated by comparing them with the peak height of an external standard processed on the same day after correcting for differences in the height of the internal standard in the test and control samples. All calculations of arabinitol concentration were based on manual measurements of peak heights. A substantial number of results (about $70 \%$ ) reported in this paper were confirmed by replicate analyses on the same day; this practice, however, was discontinued later in the 
study. In preliminary trials retention times and relative response factors for arabinitol and the internal standards were established by preparing a set of standard solutions of arabinitol in distilled water at concentrations of $2 \cdot 0,4 \cdot 0,5 \cdot 0,6 \cdot 0$, and $8 \cdot 0 \mu \mathrm{g} / \mathrm{ml}$ and treating these as for a serum specimen. Repeated analyses, with a minimum of four at each concentration, showed a linear correlation between peak height and concentration over the range of concentrations tested. The overall experimental error was 0.02 and the mean (SD) ratio of observed:expected value of arabinitol measured against the a-methyl-Dmannoside internal standard was $0.94(0 \cdot 11)$. A typical series of routine analyses of the $5 \mu \mathrm{g} / \mathrm{ml}$ pooled serum standard taken over two months showed a mean (SD) ratio of observed:expected values of $0.90(0.08)$. There was no significant difference in the reproducibility of the aqueous or serum standards as determined by the Siegel and Tukey modification of the Wilcoxon sum of rank tests. ${ }^{20}$ All serum specimens were held at $+4^{\circ} \mathrm{C}$ until processing and then stored at $-20^{\circ} \mathrm{C}$. Creatinine results were those reported on the same day that the serum for arabinitol estimations was collected.

\section{Results}

NORMAL SERA

Ten serum samples from normal healthy laboratory workers yielded arabinitol concentrations of less than $1.0 \mu \mathrm{g} / \mathrm{ml}$ (mean $0.55(0.05)$ ).

PATIENTS FOR WHOM A DIAGNOSIS OF INVASIVE CANDIDOSIS WAS EXCLUDED

Fifty eight of the 95 patients studied had arabinitol concentrations below $1.2 \mu \mathrm{g} / \mathrm{ml}$ and were considered not to have invasive candidosis. The range of arabinitol concentrations found in the serum samples of these patients, who all had normal renal function, was $0-1.0$ with a mean (SD) of $0.59(0.26)$-where more than one specimen was examined only the maximum value was used in these calculations. By applying the mean +2 SD rule the upper limits of normal for patients without a systemic infection and with normal renal function was estimated as $1 \cdot 1(0.59+0.52)$.

A further 10 patients were not thought to have invasive infections on clinical or laboratory grounds but had arabinitol concentrations $>1.2 \mu \mathrm{g} / \mathrm{ml}$. The maximum value obtained in this group was $4.0 \mu \mathrm{g} / \mathrm{ml}$. Nine had clinically important renal failure (creatinine concentrations $>132 \mu \mathrm{mol} / \mathrm{l})$. Five were heavily colonised with yeasts and four had been treated with antibiotics for bacterial sepsis. The remaining patient, with an arabinitol concentration of $1.3 \mu \mathrm{g} / \mathrm{ml}$, seemed to have given a false positive result - a child who was feverish, not responding to antibiotics after a bone marrow transplant, but who had no other evidence of fungal infection and recovered without antifungal $\underline{\underline{0}}$ treatment.

PATIENTS WITH CONFIRMED OR PROBABLE

INVASIVE CANDIDOSIS

Table 1 shows the important clinical and laboratory evidence and the results of arabinitol testing for $\overparen{\Phi}$ 27 patients who had signs of systemic or localised invasive candidosis. Confirmation from necropsy or ${ }^{\infty}$ biopsy findings was available for six cases only, but a $\vec{\circ}$ total of 19 cases that met the criteria described $\overrightarrow{\vec{H}}$ previously were accepted as cases of confirmed or $\stackrel{\sigma}{\omega}$ probable invasive candidosis. The remaining eight $\overline{\mathrm{g}}$ also had signs of systemic infection and met the desig- $\dot{\omega}$ nated criteria, but these were more difficult to assess 6 because of candidaemia associated with infected $\infty_{\infty}^{\infty}$ intravenous lines or cannulas; and these were placed $\frac{t}{\mathrm{~N}}$ in a separate subgroup (Table 1 ).

The 19 invasive cases included two drug addicts with localised candida endophthalmitis, three $\rightarrow$ patients receiving CAPD with localised candida peritonitis and six candida septicaemias. Seven of the 19 क invasive cases had positive blood cultures, six grew $\overrightarrow{\vec{O}}$ Calbicans from more than one set of cultures, and $ळ$ one patient grew $C$ tropicalis from three sets of cultures. All but one of the patients in the invasive group had maximum arabinitol concentrations greater than $1 \cdot 1 \mu \mathrm{g} / \mathrm{ml}$ in one or more of the specimens submitted for examination. The exception was one of the drug addicts who had a severe but localised candida $\unrhd$ endophthalmitis and hepatitis (case 14). He was fever- $\vec{F}$ ish but his blood cultures remained negative. Only $\frac{0}{3}$ one patient in the invasive group did not receive systemic antifungal treatment. This was a patient receiving CAPD who eventually recovered after removal of the peritoneal catheter and the resumption? of haemodialysis. All of the treated patients who recovered and most of those who died showed clear clinical signs of improvement after antifungal treat- $\frac{0}{3}$ ment was started.

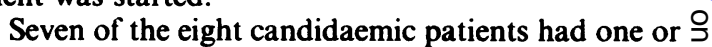
more arabinitol concentrations outside the normal $\rightarrow$ range (Table 1). The only exception was a child (case 24) who had received antifungal treatment for two $N$ days before the sample was taken. More than one sample was examined from four of the eight patients. Five of the eight had one or more positive blood $\tilde{\omega}$ cultures. The three adults and the four children, aged two or more in this subgroup, were all feverish 0 and not responding to antibiotics. The remaining two $\varnothing$ premature infants were also not responding to anti- $\stackrel{\mathcal{P}}{\rightarrow}$ biotics and had shown considerable clinical deterio- $T$ ration before sampling. Seven of the eight received $\frac{\vec{D}}{\vec{D}}$ systemic antifungal treatment and seemed, clinically, $\stackrel{\odot}{\mathcal{P}}$ to respond. The patient who did not receive anti- $\stackrel{\varnothing}{\varrho}$ 
Table 1 Arabinitol concentrations and other findings in six cases of confirmed invasive candidosis

\begin{tabular}{|c|c|c|c|c|c|c|c|c|c|}
\hline $\begin{array}{l}\text { Case } \\
\text { No. }\end{array}$ & Histology & $\begin{array}{l}\text { Culture sites } \\
\text { positive }\end{array}$ & $\begin{array}{l}\text { Date } \\
\text { sample } \\
\text { taken }\end{array}$ & $\begin{array}{l}\text { Arabinitol* } \\
(\mu \mathrm{g} / \mathrm{ml})\end{array}$ & $\begin{array}{l}\text { Dates of } \\
\text { positive blood } \\
\text { cultures }\end{array}$ & $\begin{array}{l}\text { Renal condition } \\
\text { (serum creatinine } \\
\mu m o l / l)\end{array}$ & $\begin{array}{l}\text { Treatmen } \\
\text { response }\end{array}$ & started/ & Outcome \\
\hline 1 & + & Oesophagus & $20 / 6 / 81$ & $2 \cdot 0$ & $\begin{array}{l}\text { Negative for } \\
\text { Candida sp }\end{array}$ & Normal & $23 / 6 / 81$ & positive & Died 4/7/81 \\
\hline 2 & + & Abdominal blood & $\begin{array}{l}17 / 8 / 81 \\
18 / 8 / 81 \\
20 / 8 / 81 \\
23 / 8 / 81\end{array}$ & $\begin{array}{l}0 \cdot 2 \\
0 \cdot 4 \\
0 \cdot 8 \\
1 \cdot 3\end{array}$ & $\begin{array}{l}21 \cdot 8 \cdot 81 \\
(2 \text { sets })\end{array}$ & Normal & & & $\begin{array}{l}\text { Died } 24 / 8 / 81 \\
\text { Post mortem findings } \\
\text { positive }\end{array}$ \\
\hline 3 & + & $\begin{array}{l}\text { Disseminated } \\
\text { biopsy positive } \\
26 / 10 / 81\end{array}$ & $\begin{array}{r}28 / 10 / 81 \\
29 / 10 / 81 \\
29 / 10 / 81 \\
1 / 11 / 81 \\
3 / 11 / 81\end{array}$ & $\begin{array}{l}\text { nil } \\
\text { nil } \\
\text { nil } \\
2 \cdot 1 \\
3 \cdot 0\end{array}$ & $\begin{array}{l}1 / 11 / 81 \\
3 / 11 / 81 \\
6 / 11 / 81\end{array}$ & Normal & $26 / 10 / 81$ & negative & $\begin{array}{l}\text { Died } 8 / 11 / 81 \\
\text { Post mortem findings } \\
\text { positive }\end{array}$ \\
\hline 4 & + & Abdomen blood & $5 / 2 / 82$ & 1.8 & $5 / 2 / 82$ & $\begin{array}{l}\text { Impaired renal } \\
\text { function(160) }\end{array}$ & $5 / 2 / 82$ & $?$ & Died 8/2/82 \\
\hline 5 & + & Disseminated & $\begin{array}{l}13 / 11 / 82 \\
16 / 11 / 82\end{array}$ & $\begin{array}{l}4 \cdot 0 \\
6 \cdot 3\end{array}$ & $\begin{array}{l}13 / 11 / 82 \\
16 / 11 / 82 \\
\text { (six sets) }\end{array}$ & $\begin{array}{l}\text { In total renal } \\
\text { failure on } \\
\text { haemodialysis }\end{array}$ & $13 / 11 / 82$ & negative & Died 18/11/82 \\
\hline 6 & + & Gallbladder & $\begin{array}{l}31 / 10 / 83 \\
11 / 11 / 83\end{array}$ & $\begin{array}{l}1.5 \\
1.6\end{array}$ & Negative & Normal & nil & & Died 16/11/83 \\
\hline \multicolumn{10}{|c|}{ Findings in 13 probable cases of invasive candidosis } \\
\hline 7 & & Lungs & $15 / 7 / 81$ & 1.4 & Negative & Normal & $16 / 7 / 81$ & positive & Recovered \\
\hline 8 & & Lungs & $3 / 12 / 81$ & $2 \cdot 2$ & Negative & $\begin{array}{l}\text { In total renal } \\
\text { failure on } \\
\text { haemodialysis }\end{array}$ & $30 / 11 / 81$ & positive & Died of other causes \\
\hline 9 & & $\begin{array}{l}\text { Urine, } \\
\text { stool, } \\
\text { blood }\end{array}$ & $\begin{array}{r}23 / 2 / 82 \\
8 / 6 / 82 \\
9 / 6 / 82 \\
10 / 6 / 82 \\
11 / 6 / 82 \\
16 / 6 / 82\end{array}$ & $\begin{array}{l}0 \cdot 8 \\
5 \cdot 0 \\
9 \cdot 5 \\
9 \cdot 5 \\
5 \cdot 0 \\
4 \cdot 6\end{array}$ & $\begin{array}{l}11 / 6 / 82 \\
\text { (two sets) }\end{array}$ & $\begin{array}{l}\text { Normal } \\
\text { Impaired renal } \\
\text { function (258) }\end{array}$ & $8 / 6 / 82$ & positive & $\begin{array}{c}\text { Died of leukaemia } 16 / 6 / 82 \\
\qquad \ldots\end{array}$ \\
\hline 10 & & CAPD & $\begin{array}{r}7 / 6 / 82 \\
10 / 6 / 82 \\
11 / 6 / 82 \\
11 / 6 / 82\end{array}$ & $\begin{array}{l}5 \cdot 5 \\
5 \cdot 3 \\
3 \cdot 8 \\
3 \cdot 0\end{array}$ & $\begin{array}{l}\text { Negative } \\
\text { (pre-dialysis) } \\
\text { (post dialysis) }\end{array}$ & $\begin{array}{l}\text { In total renal } \\
\text { failure }\end{array}$ & $10 / 6 / 82$ & positive & Recovered \\
\hline 11 & & $\begin{array}{l}\text { Blood } \\
\text { C tropicalis }\end{array}$ & $\begin{array}{l}10 / 7 / 82 \\
10 / 7 / 82 \\
11 / 7 / 82 \\
11 / 7 / 82 \\
12 / 7 / 82 \\
12 / 7 / 82 \\
13 / 7 / 82 \\
13 / 7 / 82\end{array}$ & $\begin{array}{l}0 \cdot 4 \\
0 \cdot 4 \\
0 \cdot 6 \\
0 \cdot 4 \\
0 \cdot 6 \\
0 \cdot 4 \\
0 \cdot 5 \\
1 \cdot 2\end{array}$ & $\begin{array}{l}12 / 7 / 82 \\
\text { (two sets) } \\
13 / 7 / 82\end{array}$ & Normal & $12 / 7 / 82$ & positive & Recovered \\
\hline 12 & & CAPD & $\begin{array}{r}9 / 9 / 82 \\
15 / 9 / 82\end{array}$ & $\begin{array}{l}3.4 \\
5 \cdot 0\end{array}$ & Negative & $\begin{array}{l}\text { In total renal } \\
\text { failure }\end{array}$ & nil & & Recovered \\
\hline 13 & & $\begin{array}{l}\text { Urine } \\
>10^{4} / \mathrm{ml} \\
(1+\rightarrow 3+)\end{array}$ & $\begin{array}{r}19 / 10 / 82 \\
11 / 11 / 82 \\
8 / 12 / 82\end{array}$ & $\begin{array}{l}0.6 \\
1.6 \\
0.6\end{array}$ & Negative & Normal & $12 / 11 / 82$ & positive & Recovered \\
\hline 14 & & Eye & $12 / 11 / 82$ & 1.0 & Negative & Normal & $12 / 11 / 82$ & positive & Recovered \\
\hline 15 & & CAPD & $\begin{array}{r}19 / 11 / 82 \\
8 / 12 / 82\end{array}$ & $\begin{array}{l}4 \cdot 5 \\
5 \cdot 8\end{array}$ & Negative & $\begin{array}{l}\text { In total renal } \\
\text { failure }\end{array}$ & nil & & Recovered \\
\hline 16 & & Lungs & $2 / 3 / 83$ & 1.9 & Negative & Normal & $23 / 3 / 83$ & positive & Recovered \\
\hline 17 & & Eye & $\begin{array}{r}5 / 4 / 83 \\
18 / 4 / 83\end{array}$ & $\begin{array}{l}1.6 \\
0.9\end{array}$ & Negative & Normal & $5 / 4 / 83$ & positive & Recovered \\
\hline 18 & & Lungs, blood & $11 / 6 / 83$ & 1.75 & $\begin{array}{r}7 / 6 / 83 \\
11 / 6 / 83\end{array}$ & Normal & $11 / 6 / 83$ & negative & Died 12/6/83 \\
\hline 19 & & $\begin{array}{l}\text { Lungs, gut } \\
\text { ? Systemic } \\
\text { ? Meninges }\end{array}$ & $\begin{array}{l}22 / 7 / 83 \\
28 / 7 / 83 \\
28 / 7 / 83 \\
4 / 8 / 83 \\
11 / 8 / 83 \\
11 / 8 / 83 \\
11 / 10 / 83 \\
11 / 10 / 83\end{array}$ & $\begin{array}{l}1.6 \\
5.3 \\
7.7 \text { cerebrospinal fluid } \\
0.4 \\
0.45 \\
3.0 \text { cerebrospinal fluid } \\
0.4 \\
3.0 \text { cerebrospinal fluid }\end{array}$ & Negative & Normal & $\begin{array}{r}22 / 7 / 83 \\
:\end{array}$ & $\begin{array}{l}\text { positive } \\
\ddots\end{array}$ & Recovered \\
\hline
\end{tabular}


Table 1-continued

\begin{tabular}{llll}
\hline $\begin{array}{l}\text { Case } \\
\text { No. }\end{array}$ & Histology $\begin{array}{l}\text { Culture sites } \\
\text { positive }\end{array}$ & $\begin{array}{l}\text { Date } \\
\text { sample } \\
\text { taken }\end{array}$ & $\begin{array}{l}\text { Arabinitol* } \\
(\mu \mathrm{g} / \mathrm{ml})\end{array}$ \\
\hline
\end{tabular}

Possibly invasive cases with infected intravenous lines

20 Adult $C$ albicans grown from central venous tip and line

$$
\begin{array}{llll}
21 / 12 / 82 & 1.5 & 21 \cdot 12.82 & \begin{array}{c}
\text { Impained renal } \\
\text { function(200) }
\end{array}
\end{array} \text { nil Recovered }
$$

21 Child 2 years, congenital problems, colonised, $C$ albicans from intravenøus cannula

$$
\begin{array}{lllll}
10 / 7 / 81 & 1.25 & 8 / 7 / 81 & \text { Normal } & 1.0 / 7 / 81 \\
17 / 7 / 81 & 1.3 & \text { positive Recovered }
\end{array}
$$

$17 / 7 / 81 \quad 1.3$

22 Child 12 years, post renal transplant, $C$ albicans from intravenous line

$$
\text { 29/12/81 2.1 Negative Normal 29/12/81 positive Recovered }
$$

23 Child, 6 years, leukaemic, receiving cytotoxic treatment, oesophageal thrush and ulceration, $\mathbb{C}$ albicans from intravenøus line

$\begin{array}{lllll}1 / 2 / 82 & 3.5 & 26 / 1 / 82 & \text { Normal } & 28 / 1 / 82 \\ 3 / 2 / 82 & 3.7 & 28 / 1 / 82 & & \text { positive Recovered }\end{array}$

24 Child, 14 years, $T$ cell lymphoma, oesophageal thrush and ulceration, $C$ albicans from intravenous line

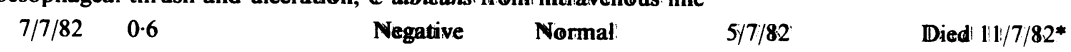

25 Premature infant, colonised, yeasts in longline and airways

$\begin{array}{llll}21 / 1 / 83 & 1.4 & \text { Negative Normal } \quad 19 / 1 / 83 \text { pøsitive Recovered }\end{array}$

26 Adult, intestinal perforation, colonised, yeasts in drains and intravenous cannula

$$
2 / 2 / 83 \quad 1.6 \quad 2 / 2 / 83
$$

In total renal $\quad 2 / 2 / 83$

failune on

haemodialysis

27 Infant, oesophageal thrush and ulceration, $C$ albicans also in intravenous line

$\begin{array}{lllll}21 / 9 / 81 & 1.4 & 15 / 9 / 81 & \text { Normal } & 17 / 9 / 81 \\ 25 / 9 / 81 & 1.4 & & & \end{array}$

*Death due to multiple causes including septicaemia, pancytopenia, and liver failure.

$\mathrm{CAPD}=$ Continuous ambulatory peritoneal dialysis.

fungal drugs had been admitted to intensive care because of breathing difficulties associated with a Guillain Barre syndrome. She had some renal impairment (Table 1) with an a:c ratio of 0.66, suggesting that the raised arabinitol was not clinically important $^{15}$ and that the growth of Calbicans firom central venous line and tip was not associated with a systemic spread.

\section{CHILDREN WITH PROBABLE INVASIVE} CANDIDOSIS

A total of eight cases of probable candidosis were diagnosed in children or infants under the age of 14 years. As detailed in Table 1 , six cases in all had a candidaemia as shown by the isolation of Candidida yeasts from infected longlines ${ }^{6}$ or blood cultures, or both. ${ }^{3}$ There was also one case of confidently diagnosed systemic candidosis with heavy growths of Candida albicans in lung aspirates and clinical sigms of meningitis but with negative blood cultures: (see below), and one case of Candida peritonitis in an 8 year old patient receiving CAPD. All except ome of the children received antifungal treatment, and where necessary, all had their lines or catheter tips changedl.
Eighth of the nime patients, suabsequently recovered.

Setsi of matiched blorod andl cerebrosppimall filhuids; in one case of probable syst temic camdtidtosis proxiaded an unusuall opportumity to connpare the paired results of amabimitiol estimmatioms: in blood and cerebrospimal

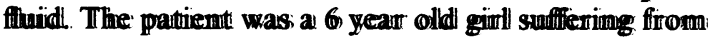

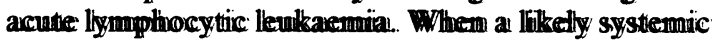
flungall infiection was dliagmosed sthe was pamcytoparenic, feveristh, and mot respondings, to broad spectrum antilbiotics. She hard a wirdespreard colomisation:

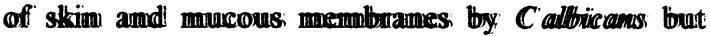
Hloodl culturnes; were megatiine. The Fingume sthows durration of treatument aund the comcentrations. of anabimittoll in semum and cerebrospimall flituidl. The first

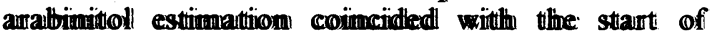
treatument with amuphottericiim B. Remail fumctiom at this time was, mormaall. Iheititially's, sthe secmedt to immpprove buat afther ome week of antiffumgail treattmenti sthe colliapsed with clinicall sigms; of cerrebrall spreadl and requiured intemsixe liffe stupppentimg meassures. At this: point

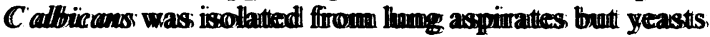
were wot detectied in the cerebrospimall fithuid. The

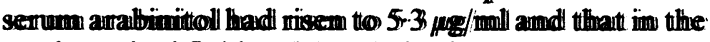

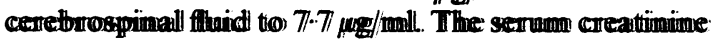




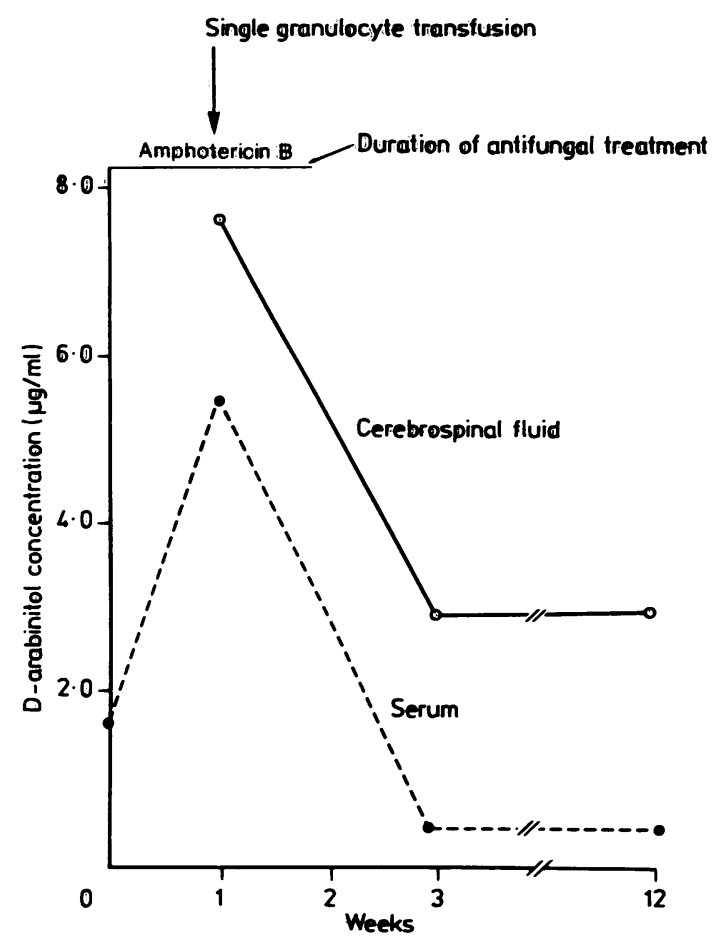

Duration of antifungal treatment and arabinitol concentrations in paired sera and cerebrospinal fluids of a 6 year old girl with acute lymphocytic leukaemia.

at this time was $90 \mu \mathrm{mol} / 1$, the upper limit of normal at this age. Treatment with amphotericin B was stopped after 10 days because of hepatotoxicity and failing renal function. Subsequently, renal function returned to normal and the child's condition slowly improved. After two weeks the serum arabinitol had returned to normal and after a further week it was still unchanged. The cerebrospinal fluid value at this time was $3.0 \mu \mathrm{g} / \mathrm{ml}$. The final paired set of serum and cerebrospinal fluid examined some two months later yielded similar results with the cerebrospinal fluid value still above that of the serum. At this time she was considered to be clinically free of Candida infection.

\section{MULTIPLE SAMPLING}

The value of obtaining multiple samples from patients suspected of developing deep seated candidosis was confirmed during the course of the study. Weekly samples of serum from a patient in a recognised high risk category showed that in the absence of infection arabinitol concentrations remained consistently low. By contrast, repeat samples from patients with suspected candidosis showed that the drawing of multiple samples could considerably improve the diagnostic value of the test by indicating a rising concentration of arabinitol. These changes could often be correlated with a deteriorating clinical condition. A response to treatment could also be seen to correlate with a falling concentration of arabinitol; there was, however, insufficient data to determine whether arabinitol concentrations could be used to indicate that treatment could be safely withdrawn. An increase in diagnostic yield was obtained with seven of the 14 cases with multiple samples (Table 1), and taken overall, diagnosis was aided in 18 of the 33 cases $(55 \%)$.

The negative series was obtained from an 18 year old man undergoing bone marrow transplant. Weekly mycological screening of mouth, throat, rectal and skin swabs was combined with weekly monitoring of arabinitol concentrations. The first 10 samples taken over the same period of weeks showed that in the absence of mycological evidence of colonisation the arabinitol value remained consistently normal, mean $0.5(0 \cdot 1) \mu \mathrm{g} / \mathrm{ml}$. At the first signs of colonisation, however, detected in a throat swab after 11 weeks, the arabinitol concentration had risen to $1.6 \mu \mathrm{g} / \mathrm{ml}$. This was, however, an isolated false positive result, and samples taken over the next five weeks were all in the normal range. The patient remained without fever throughout the full 16 weeks of monitoring and showed no signs of developing deep seated or invasive candidosis.

More than one serum sample was obtained from 33 patients in the study. Multiple samples were obtained from 10 adults and two children in the invasive group and from two children and two infants in the probably invasive but candidaemic subgroup. Increases in arabinitol concentration in a patient's serum often occurred at or about the time that yeasts were detected in blood cultures. In the cases where the first positive arabinitol result coincided with the first positive blood culture the arabinitol result was available on the day of sampling, whereas the blood culture result was not known until 48-72 hours later. The findings reported here confirm and extend the observations of previous investigators. ${ }^{15}$

\section{ARABINITOL AND RENAL FAILURE}

During this study Wong et al ${ }^{14}$ described the 1:1 relation between arabinitol and creatinine excretion under conditions of normal renal function and in a later paper, that an arabinitol:creatinine (a:c) ratio of 1.4:1 was the lower limit of significance that was consistent with invasive candidosis in a patient with renal impairment. ${ }^{15}$ In this study eight of the 27 patients exhibited clinically important renal failure (Table 1). Arabinitol concentrations in these patients were generally higher than in patients with normal renal function, although the highest individual concentra- 
Table 2 Arabinitol:creatinine ratios in sera of six patients in renal failure not receiving dialysis

\begin{tabular}{lllll}
\hline Case No & Diagnosis & Arabinitol $(\mu \mathrm{g} / \mathrm{ml})$ & Creatinine* $(\mathrm{mg} /$ dl) & a:c ratio \\
\hline 1 & Colonised & 0.6 & 1.13 & 0.53 \\
2 & Colonised & 1.3 & 2.8 & 0.46 \\
3 & Candida cystitis & 0.0 & 1.73 & 0.57 \\
& & 1.6 & 2.0 & 0.3 \\
4 & Candidaemia & 0.6 & 1.3 & 0.51 \\
5 & Calbicans peritonitis & 1.5 & 2.17 & 0.65 \\
6 & and septicaemia & 1.8 & 1.8 & 1.0 \\
& Leukaemic with systemic & 0.8 & 0.8 & \\
& candidosis & 5.0 & 1.39 & 6.83 \\
& & 9.5 & 1.39 & 6.83 \\
& 9.5 & 3.0 & 1.66 \\
\end{tabular}

* Results in $\mu \mathrm{mol} / 1$ multiplied by $0 \cdot 0113$, according to Wong et al. ${ }^{14}$

tions of $9.5 \mu \mathrm{g} / \mathrm{ml}$ was from a patient without renal problems at the time.

Table 2 shows the results obtained with a group of six patients in renal failure who were not receiving dialysis. All creatinine results were converted from $(\mu \mathrm{mol} / \mathrm{l})$ to traditional $(\mathrm{mg} / \mathrm{dl})$ units, using the multiplication factor of 0.0113 before calculating the a:c ratio, as described by Wong et al. ${ }^{14}$ In the colonised or superficially infected cases and in the case of candidaemia (case 4 ) the a:c ratios were $<1 \cdot 0$, suggesting that the raised arabinitol concentrations $(>1.0 \mu \mathrm{g} / \mathrm{ml})$ in two of the three cases were caused by renal failure rather than invasive disease. This conclusion was also consistent with the clinical findings in each case. The a:c ratio exceeded 1.2 in two of the three invasive cases but only in one did it exceed 1.4 , the lowest value of likely significance suggested by Gold et al. ${ }^{15}$

Table 3 gives the detailed results obtained from the sera of three patients undergoing CAPD with confirmed candida peritonitis. Raised arabinitol concentrations were found in all three patients. (The sera from the patient with $C$ parapsilosis peritonitis were taken only after the patient had completed a 21 day course of ketoconazole.) The single set of paired predialysis and post dialysis sera obtained from one patient (case 3) showed that on this occasion there was only a relatively small reduction in the serum arabinitol concentration.

\section{Discussion}

The publication of techniques for the estimation of D-arabinitol concentrations in patients' sera and the evidence that this polyol is a major metabolite of the clinically important Candida species of yeasts were important developments in the search for new and more specific techniques for the diagnosis of invasive candidosis. The present study was undertaken to evaluate this approach prospectively and was carried out without prior selection of the patients included on the basis of any particular underlying disease. The lack of selection simulates the likely use of the test in a diagnostic laboratory context.

This study confirms that arabinitol is present in small amounts in the sera of uninfected and otherwise healthy subjects, as well as in patients who are colonised, or superficially infected, with strains of

Table 3 Arabinitol concentrations in serum of patients with confirmed candida peritonitis while on continuous ambulatory peritoneal dialysis (CAPD)

\begin{tabular}{|c|c|c|c|c|}
\hline & Date serum taken & Arabinitol $(\mu \mathrm{g} / \mathrm{ml})$ & Dates treated & Outcome \\
\hline $\begin{array}{l}1 \text { CAPD Candida parapsilosis } \\
\text { peritonitis }\end{array}$ & $\begin{array}{r}9 / 9 / 82 \\
15 / 9 / 82\end{array}$ & $\begin{array}{l}3.4 \\
5 \cdot 0\end{array}$ & $\begin{array}{r}3 / 8 / 82 \\
17 / 8 / 82\end{array}$ & Recovered \\
\hline $\begin{array}{l}2 \text { CAPD Candida albicans } \\
\text { peritonitis }\end{array}$ & $\begin{array}{l}19 / 11 / 82 \\
10 / 12 / 82\end{array}$ & $\begin{array}{l}4 \cdot 5 \\
5 \cdot 8\end{array}$ & $\begin{array}{c}\text { Nil; catheter } \\
\text { taken out }\end{array}$ & Recovered \\
\hline $\begin{array}{l}3 \text { CAPD Candida albicans } \\
\text { peritonitis }\end{array}$ & $\begin{array}{r}7 / 6 / 82 \\
10 / 6 / 82 \\
11 / 6 / 82 \\
11 / 6 / 82\end{array}$ & $\begin{array}{l}5 \cdot 5 \\
5 \cdot 3 \\
3 \cdot 8 \text { (pre-dialysis) } \\
3 \cdot 0 \text { (post dialysis) }\end{array}$ & $\begin{array}{l}7 / 6 / 82-18 / 6 / 82 \\
\text { and catheter } \\
\text { taken out }\end{array}$ & Recovered \\
\hline
\end{tabular}


Candida yeasts. The value of $1 \cdot 1$ was shown to be the upper limit of normal (defined as the mean $+2 \times$ the standard deviation) for 58 patients who had normal renal function and who were not thought to have deep seated candidosis, thus confirming the normal range quoted by previous workers. ${ }^{8915}$ The study has shown that increased concentrations of circulating arabinitol are associated with the more invasive forms of candidosis. Increases also occur, however, in patients with impaired renal function who are without detectable signs of invasive candidosis, and occasionally small increases can occur in a small number of patients with normal renal function who probably do not have either localised invasive or systemic spread of Candida infection. ${ }^{21}$

Limited experience with patients in renal failure supports the use of the a:c ratio in patients with renal failure who are not receiving dialysis, but until evidence from a greater number of cases is available, considerable caution is indicated in this area. It may, indeed, prove impossible to enunciate a precise single value of significance for a:c ratios.

Preliminary results with patients on dialysis suggest that there will be other difficulties of interpretation in these patients. It is not clear whether the a:c ratio can be reliably applied to patients receiving either CAPD or haemodialysis. As shown in the results (Table 3) there is some evidence that the serum concentrations of creatinine fall more quickly than that of arabinitol during dialysis. Eng et al ${ }^{11}$ also reported a case in which there was only a small decrease in the arabinitol concentration after dialysis.

It is not possible to quote accurate figures for the sensitivity or specificity of the analysis, when proof of invasiveness is not available for most clinically invasive cases, but if the 27 cases detailed in Table 1 are accepted as positives for the purposes of approximation the sensitivity is $92.5 \%$ and the specificity $88.2 \%$. These results confirm the findings of Gold et al, ${ }^{15}$ who reported a sensitivity of $84 \%$ and a specificity of $93 \%$. Other prospective studies published while this work was in progress report similar findings. ${ }^{1112}$ By contrast to these findings, however, de Repentigny et al reported a low sensitivity of only $26 \%$ (together with a specificity of $87 \%$ ) in their recent comparative studies. ${ }^{17}$ Technical modifications introduced by these workers may have contributed to the discrepancy in sensitivity values noted by them. ${ }^{22}$

A simple, reproducible, and rapid test is needed in the diagnostic laboratory, and in this respect the estimation of arabinitol concentration is a practical proposition. With an analysis time of under two hours per specimen there is no requirement to batch analyses and it is possible to process five to six specimens comfortably in a day. The method of sample preparation is simple but requires a fume cupboard for handling the TMS reagents. The chromatography is relatively straightforward for the experienced operator, but the capital cost of the equipment and the nature of the test suggests that it is best restricted to the larger general hospital.

The examination of multiple samples has been shown to improve the diagnostic value of the analysis, but as only a small number of patients have been followed up with adequate numbers of serum samples throughout the development of their disease and its subsequent resolution with treatment, it is impossible to determine whether or not there is a typical time required for metabolite values to return to normal, as suggested by Miller et al. ${ }^{7}$ Similarly, the utility of monitoring the fall in arabinitol concentrations to determine the duration of treatment has also not been established, but the absence of a falling arabinitol concentration may indicate ineffective treatment.

The normal range for serum arabinitol in the serum of infants has yet to be established, and it is possible that the normal concentrations in infants will not prove to be the same as those in adults. Factors such as the age of the infant, the immaturity of the kidneys or some metabolic functions, or relatively short term changes in the state of hydration may affect the amounts of arabinitol detected in a random sample of serum. Further studies are in progress.

The observation that the arabinitol concentrations in the cerebrospinal fluid of one child were higher than in her serum was unexplained at the time, but the results suggested a baseline value of $3.0 \mu \mathrm{g} / \mathrm{ml}$. No inborn errors of pentose metabolism had been detected $^{23}$ and there were no published normal values, but there had been one isolated report of similar raised concentrations in a case of candida meningitis. ${ }^{11}$ Subsequently, the Sloan Kettering group confirmed that the normal values in cerebrospinal fluid were higher with a mean of about $3.0 \mu \mathrm{g} / \mathrm{ml}$ (D Armstrong, personal communication). Scheld et al ${ }^{24}$ then reported that the mean normal value in the cerebrospinal fluid of rabbits and of man was 3.4 $(0.2) \mu \mathrm{g} / \mathrm{ml}$ (mean (SD)). To date results on six cerebrospinal fluid samples from children and adults in this laboratory show a similar pattern (unpublished data).

In common with other infectious diseases, the development of systemic candidosis in a patient is likely to be determined by the interplay between factors such as the number of infecting yeasts at the site, the availability of nutrients, the growth rates and virulence of the infecting strain, and the host defences. ${ }^{11} 15$ Similarly, the production of abnormally high amounts of serum arabinitol will also depend on these factors and on the rate of its excretion by the kidneys. ${ }^{15}$ Such complex interactions 
readily explain why the test occasionally fails to confirm a positive diagnosis, or only yields a positive finding late in the disease process. Another cause of false negative or delayed positive results may be due to quantitative differences in the amounts of arabinitol produced by different strains or species of yeasts. ${ }^{10}$

False positive results may occur when there is a heavy superficial colonisation, or infection restricted to superficial mucosa in tissues that are normally sterile. Some evidence was seen during this study, which suggested that such circumstances could arise in patients with large areas of trauma leading to extensive colonisation of normally internal surfaces. It is also possible that intestinal obstruction occurring in a patient who is colonised with yeasts could lead to an overgrowth in the gut with very high numbers of yeasts producing greater than normal amounts of arabinitol. Even if only a proportion of this was absorbed from the gut it could lead to increased serum concentrations in a patient with normal renal function. Such findings in patients with complex clinical problems undergoing a high degree of medical manipulation or receiving extensive supportive treatment can pose major difficulties in interpreting laboratory results.

It is possible that the limitations of this approach, identified in this and other similar studies in the United States, ${ }^{8911}$ may be compensated for by the concurrent use of other recently described methods for diagnosis, including the detection of circulating antigen by latex agglutination, ${ }^{25}$ enzyme linked immunoassay or radioimmunoassay for antigen or antibody detection, ${ }^{26-28}$ or by a combination of the arabinitol approach with other gas-liquid chromatography methods. ${ }^{1617}$ At present a full diagnostic service in this difficult area seems to require a combination of techniques, and the results of this study suggest that arabinitol estimations are worthy of careful consideration in those laboratories that are appropriately equipped.

I thank Drs SR Alcock and LJR Milne for their helpful advice in preparing the manuscript, $\operatorname{Dr} \mathbf{A}$ Speekenbrink for his help with statistical analyses, and the many clinical colleagues who provided serum specimens and information on their patients.

References

${ }^{1}$ Odds FC. Candida and candidosis. Leicester: Leicester University Press, 1979.

${ }^{2}$ Seelig MS, Kozinn PJ. Clinical manifestions and management of candidosis in the compromised patient. In: Warnock DW, Richardson MW, eds. Fungal infection in the compromised patient. Chichester: John Wiley, 1982:49-92.

${ }^{3}$ Hart PD, Russell E Jr, Remington JS. The compromised host and infection II: deep fungal infection. J Infect Dis 1969;129:169-91.

${ }^{4}$ Roberts GD, Washington II JA. Detection of fungi in blood cultures. J Clin Microbiol 1975;1:309-10.

${ }^{5}$ Bennett JE. Diagnosis and management of candidosis in the immunosuppressed host. Scand J Infect Dis 1978;16(suppl):83-6.

${ }^{6}$ de Repentigny L, Reiss E. Current trends in immunodiagnosis of candidiasis and aspergillosis. Rev Infect Dis 1984;6:301-12.
${ }^{7}$ Miller GG, Witwer MW, Braude AI, Davis CE. Rapid identification of Candida albicans septicemia in man by gas- 으 liquid chromatography. J Clin Invest 1974;58:1235-40.

${ }^{8}$ Kiehn TE, Bernard EM, Gold JWM, Armstrong D. Candidosis: detection by gas-liquid chromatography of D-arabinitol, a fungal metabolite, in human serum. Science 1979;206:577-80.

${ }^{9}$ Roboz J, Suzuki R, Holland JF. Quantification of arabinitol in $\overline{0}$ serum by selected ion monitoring as a diagnostic technique in $\overline{\mathrm{\sigma}}$ invasive candidosis. J Clin Microbiol 1980;12:594-602

10 Bernard EM, Christiansen KJ, So-Fai Tsang, Kiehn TE, @ Armstrong D. Rate of arabinitol production by pathogenic yeast species. J Clin Microbiol 1981;14:189-94.

11 Eng RHK, Chmel H, Buse M. Serum levels of arabinitol in the $\vec{\odot}$ detection of invasive candidosis in animals and humans. $J$ Infect Dis 1981;143:677-83.

12 Wells CL, Sirany MS, Blazevic DJ. Evaluation of serum arabinitol as a diagnostic test for candidosis. J Clin Microbiol 1983;18: 353-7.

${ }^{13}$ Wong B, Bernard EM, Gold JWM, Fong D, Silber A, Armstrong D. Increased arabinitol levels in experimental can- $\infty$ didosis in rats: arabinitol appearance rates, arabinitol/creatinine $\infty$ ratios, and severity of infection. J Infect Dis 1982;146:346-52. त

14 Wong B, Bernard EM, Gold JWM, Fong D, Armstrong D. The 0 arabinitol appearance rate in laboratory animals and humans: estimation from the arabinitol-creatinine ratio and relevance to the diagnosis of candidosis. J Infect Dis 1982;146:353-9.

15 Gold JWM, Wong B, Bernard EM, Kiehn TE, Armstrong D. فे Serum arabinitol concentrations and arabinitol/creatinine ratios $\frac{C}{\mathcal{A}}$ in invasive candidosis. J Infect Dis 1983;147:504-13.

${ }^{16}$ de Repentigny L, Kuykendall RJ, Chandler FW, Broderson JR, $\overrightarrow{0}$ Reiss $\mathrm{E}$. Comparison of serum mannan, arabinitol and mannose $\infty$ in experimental disseminated candidiasis. $J$ Clin Microbiol 1984;19:804-12.

${ }^{17}$ de Repentigny L, Marr LD, Keller JW, et al. Comparison of $\stackrel{\bigcirc}{\Sigma}$ enzyme immunoassay and gas-liquid chromatography for the rapid diagnosis of invasive candidiasis in cancer patients. $J$ Clin $O$ Microbiol 1985;21:972-9.

${ }^{18}$ Bayer AS, Blumenkrantz MJ, Montgomerie JZ, Galpin J, Coburn $\stackrel{\mathbb{D}}{\stackrel{2}{2}}$ JW, Guze LB. Candida peritonitis. Report of 22 cases and $\vec{F}$ review of the English literature. Am J Med 1976;61:832-40.

${ }^{19}$ Sweeley CC, Bentley R, Makita M, Wells WW. Gas-liquid chro- 3 matography of trimethylsilyl derivatives of sugars and related substances. Journal of the American Chemical Society 1963;85: 2497-507.

${ }^{20}$ Langley R, Practical statistics. London: Pan Books Ltd, $\frac{\widehat{O}}{\overparen{O}}$ 1968:175-6.

${ }^{21}$ Karam GH, Elliott AM, Polt S, Cobbs CG. Elevated serum D- 윽 arabinitol levels in patients with sarcoidosis. $J$ Clin Microbiol 1984;19:26-9.

22 Wong B, Bernard EM, Armstrong D, Roboz J, Suzuki R, Holland JF. Evaluation of the aldonitrile peracetate method for 0 measuring arabinitol in serum. $J$ Clin Microbiol 1985;21:478-9. I

${ }^{23}$ Touster $\mathrm{O}$, Harwell SO. The isolation of $\mathrm{L}$-arabinitoll from pento- $D$ suric urine. J Biol Chem 1958;239:1031-41.

${ }^{24}$ Scheld WM, Lee D, Bernard EM, Wong B, Armstrong D. CSF arabinitol in experimental Candida albicans meningitis. o 24th Interscience Conference on Antimicrobial Agents and Chemotherapy. Washington, DC: American Society for Microbiology, 1984

25 Gentry LO, Wilkinson ID, Lea AS, Price MF. Latex agglutination test for detection of candida antigen in patients with dissem- $<$ inated disease. Eur J Clin Microbiol 1983;2:122-8.

${ }^{26}$ Kostiala AAI, Kostiala I. Enzyme-linked immunosorbent assay (ELISA) for IgM, IgG, and IgA class antibodies against Candida albicans antigens: development and comparison and $T$ other methods. Sabouraudia 1981;19:123-34.

27 Warren RC, Bartlett A, Bidwell DE, Richardson MD, Voller A, White LO. Diagnosis of invasive candidosis by enzyme immunoassay of serum antigen. $\mathrm{Br} \mathrm{Med} J$ 1977:i:1183-5.

${ }^{28}$ Cobb SJ, Parratt D. Determination of antibody levels to Candida albicans in healthy and hospitalised adults using a radioimmunoassay. J Clin Pathol 1978;31:1161-6.

Requests for reprints to: Dr AG Deacon, Department of Bacteriology and Immunology, Western Infirmary, Glasgow G11 6NT, Scotland. 